\title{
Efflcacy of intermittent pneumatic compression for venous thromboembolism prophylaxis in patients undergoing gynecologic surgery: A systematic review and meta-analysis
}

\author{
Jian-Ping Feng ${ }^{1}$, Yu-Ting Xiong ${ }^{2}$, Zi-Qi Fan ${ }^{1}$, Li-Jie Yan ${ }^{1}$, Jing-Yun Wang ${ }^{1}$, Ze-Juan \\ $\mathbf{G u}^{3}$ \\ ${ }^{1}$ Department of Anesthesiology, The First Affliated Hospital of Nanjing Medical University, Nanjing 210029, Jiangsu Province, \\ China \\ ${ }^{2}$ Department of Nursing, The Second Affliated Hospital of Wannan Medical College, Wuhu 241000, Anhui Province, China \\ ${ }^{3}$ Department of Nursing, The First Affliated Hospital of Nanjing Medical University, Nanjing 210029, Jiangsu Province, China \\ Correspondence to: Ze-Juan Gu, email: jassicagu@163.com \\ Keywords: gynecologic surgery, pulmonary embolism, deep vein thrombosis, intermittent pneumatic compression, heparin \\ Received: August 08, 2016 Accepted: November 07, 2016 Published: November 25, 2016
}

\section{ABSTRACT}

We sought to comprehensively assess the efflcacy of Intermittent Pneumatic Compression (IPC) in patients undergoing gynecologic surgery. A computerized literature search was conducted in Pubmed, Embase and Cochrane Library databases. Seven randomized controlled trials involving 1001 participants were included. Compared with control, IPC signiflcantly lowered the deep vein thrombosis $(D V T)$ risk [risk ratio $(R R)=0.33,95 \%$ confldence interval $(C I): 0.16-0.66$ ]. The incidence of DVT in IPC and drugs group was similar $(4.5 \%$ versus. $3.99 \%, R R=$ $1.19,95 \%$ CI: $0.42-3.44)$. With regards to pulmonary embolism risk, no signiflcant difference was observed in IPC versus control or IPC versus drugs. IPC had a lower postoperative transfusion rate than heparin ( $R R=0.53,95 \% \mathrm{CI}: 0.32-0.89$ ), but had a similar transfusion rate in operating room to low molecular weight heparin $(R R=1.06,95 \%$ CI: $0.69-1.63)$. Combined use of IPC and graduated compression stockings (GCS) had a marginally lower risk of DVT than GCS alone (RR $=0.38$, 95\% CI: $0.14-1.03)$. In summary, IPC is effective in reducing DVT complications in gynecologic surgery. IPC is neither superior nor inferior to pharmacological thromboprophylaxis. However, whether combination of IPC and chemoprophylaxis is more effective than IPC or chemoprophylaxis alone remains unknown in this patient population.

\section{INTRODUCTION}

The incidence of venous thromboembolism (VTE) is more than 100 persons per 100000 , and increases with advancing age [1]. The morbidity and mortality of VTE remain high despite the improved prophylaxis, due to various risk factors, such as surgery, trauma, malignancy, hospital, increasing age, lower extremity paresis and so on [2]. Pulmonary embolism (PE) and deep vein thrombosis (DVT) are two main manifestations of symptomatic VTE. There is an increased risk of VTE in perioperative patients. It was reported that there was averagely an incidence of symptomatic VTE of $0.8 \%$ within 3 months after operation, and up to $3 \%$ in high-risk procedures [3]. Taking into account the fact that approximately $50 \%$ of DVT are silent [4], the true frequency of postoperative VTE may even much higher.

Thromboprophylaxis is demonstrated essential in reducing morbidity and mortality of VTE. Low molecular weight heparin (LMWH) is a main recommended thromboprophylaxis for patients undergoing major general surgery. The preventive recommendations for VTE in major gynecologic surgery are similar to that in general surgery [5]. Nonetheless, bleeding risks have precluded the clinical use of antithrombotic drugs $[6,7]$. Intermittent pneumatic compression (IPC) is also a recommendation for VTE prophylaxis in patients 
undergoing major gynecologic surgery for benign disease or malignancy, particularly in patients who are at high risk for major bleeding complications [8, 9]. However, existing guidelines are mainly based on evidence from general surgery, while women undergoing gynecologic surgeryhave additional risk factors for VTE, including oral contraceptive use, estrogen therapy, postpartum period, lithotomy position, malignancy accompanied by high estrogen level, extensive pelvic anatomy and lengthy abdominal and pelvic surgery $[10,11]$. Thus evidence generated from studies involving general surgery and men may not be completely suitable for women with gynecologic procedures. Besides, there were few randomized controlled trials (RCT) evaluating the use of IPC in gynecologic surgery at the time of the guidelines publication, and the subsequent studies may further increase our understanding on this topic. Therefore, we conducted this meta-analysis, with aims to comprehensively assess the efficacy of IPC in patients undergoing gynecologic surgery, by means of currently available data.

\section{RESULTS}

\section{Characteristics of included studies}

The literature search and study selection strategy is shown in Figure 1.

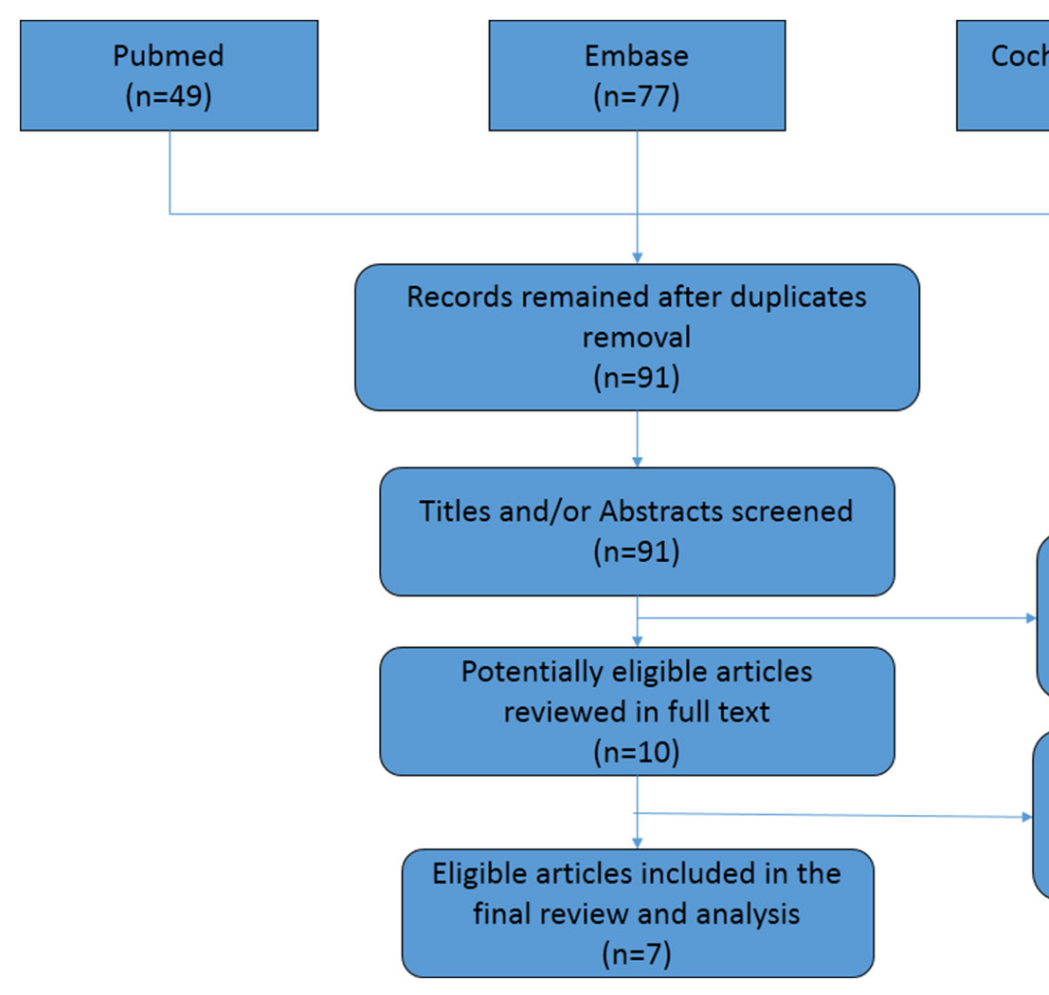

A total of 130 citations were initially identified, of which only 7 articles involving 1001 participants were finally included in the analysis [12-18]. Most studies had a low risk of bias (Supplementary Figure 1). Publication bias was shown in Supplementary Figure 2 . The messages on treatments group, regimen, sample size and follow up duration were summarized in Table 1. Two studies compared IPC with control [12, 13], of which one used IPC in the perioperative period only (short-dated IPC) [13]. Three trials compared IPC with drugs (heparin or LWMH) [14, 15, 18]. One trial had 3 arms: IPC, LWMH and control [16]. The study by Gao et al. compared a combination of IPC and graduated compression stockings (GCS) with GCS alone, and considered two lower limbs as two samples when calculating DVT rate [17]. As shown in Table 2, a majority studies included patients undergoing major surgery for known or presumed gynecologic malignancies $[12-15,18]$. Two studies involved patients undergoing gynecological pelvic surgery with highrisk factors for DVT [16, 17]. However, that 2 study had gynecologic malignancies of $29.4 \%$ and $32.4 \%$, respectively.

\section{IPC use for DVT prophylaxis}

All included studies reported the incidence of DVT. As shown in Figure 2, compared with control, routine IPC use significantly lowered the DVT risk (RR

Figure 1: Flow chart of literature search and selection. 
Table 1: Summary of randomized controlled studies on the effect of IPC on DVT and PE

\begin{tabular}{|c|c|c|c|c|c|c|}
\hline Study/Country & Year & Treatments & Number & Regimen & Endpoints & Follow-up \\
\hline \multirow[t]{2}{*}{$\begin{array}{l}\text { Clarke Pearson } \\
\text { and Synan et al. } \\
\text { America }\end{array}$} & 1984 & IPC & 55 & $\begin{array}{l}\text { Started at the time of induction } \\
\text { of anesthesia and maintained for } \\
5 \text { postoperative days. }\end{array}$ & $\begin{array}{c}\text { DVT and/or PE: } 7 \\
\text { PE: } 2\end{array}$ & 42 days \\
\hline & & Control & 52 & None & $\begin{array}{c}\text { DVT and/or PE: } \\
18 \\
\text { PE: } 1\end{array}$ & 42 days \\
\hline \multirow[t]{2}{*}{$\begin{array}{l}\text { Clarke Pearson } \\
\text { and Creasmann } \\
\text { et al. } \\
\text { America }\end{array}$} & 1984 & IPC & 97 & $\begin{array}{l}\text { Applied at the time of induction } \\
\text { of anesthesia until discharge } \\
\text { from the recovery room or } 24 \\
\text { hours post operation. }\end{array}$ & $\begin{array}{l}\text { VTE: } 18 \\
\text { PE: } 4\end{array}$ & 42 days \\
\hline & & Control & 97 & None & $\begin{array}{l}\text { VTE: } 12 \\
\text { PE: } 1\end{array}$ & 42 days \\
\hline \multirow[t]{2}{*}{$\begin{array}{l}\text { Clarke-Pearson } \\
\text { and Synan et al. } \\
\text { America }\end{array}$} & 1993 & IPC & 101 & $\begin{array}{l}\text { Initiated at the induction of } \\
\text { anesthesia and continued for } 5 \\
\text { postoperative days. }\end{array}$ & $\begin{array}{l}\text { DVT: } 4 \\
\text { PE: } 0\end{array}$ & 30 days \\
\hline & & Heparin & 107 & $\begin{array}{l}5000 \text { units at } 2 \text { PM, } 10 \text { PM, and } \\
6 \text { AM before starting surgery and } \\
5000 \text { units every } 8 \text { hours for } 7 \\
\text { postoperative days; or until full } \\
\text { ambulation or discharge. }\end{array}$ & $\begin{array}{l}\text { DVT: } 7 \\
\text { PE: } 0\end{array}$ & 30 days \\
\hline \multirow[t]{2}{*}{$\begin{array}{l}\text { Maxwell et al. } \\
\text { America }\end{array}$} & 2001 & IPC & 106 & $\begin{array}{l}\text { Started at the time of induction } \\
\text { of anesthesia and continued for } 5 \\
\text { postoperative days. }\end{array}$ & $\begin{array}{l}\text { DVT: } 1 \\
\text { PE: } 0\end{array}$ & 30 days \\
\hline & & LMWH & 105 & $\begin{array}{l}\text { Received } 2500 \text { units } \\
\text { subcutaneously before surgery, } \\
\text { and then received a daily dose } \\
\text { of } 5000 \text { units until the } 5^{\text {th }} \text { day or } \\
\text { discharge. }\end{array}$ & $\begin{array}{l}\text { DVT: } 2 \\
\text { PE: } 0\end{array}$ & 30 days \\
\hline \multirow[t]{3}{*}{$\begin{array}{l}\text { Yang et al. } \\
\text { China }\end{array}$} & 2009 & IPC & 47 & $\begin{array}{l}\text { Applied at the time of induction } \\
\text { of anesthesia until ambulation. }\end{array}$ & DVT: 4 & 5 days \\
\hline & & LMWH & 48 & $\begin{array}{c}\text { 5000IU the night before } \\
\text { operation and continued for } 5 \\
\text { days. }\end{array}$ & DVT: 1 & 5 days \\
\hline & & Control & 48 & None & DVT: 10 & 5 days \\
\hline \multirow[t]{2}{*}{$\begin{array}{l}\text { Gao et al. } \\
\text { China }\end{array}$} & 2012 & $\mathrm{IPC}+\mathrm{GCS}$ & 52 & $\begin{array}{l}\text { Applied GCS pre-operatively } \\
\text { and IPC intra- and post- } \\
\text { operatively until ambulation. }\end{array}$ & $\begin{array}{l}\text { DVT: } 5 / 104 \\
\text { (limbs) } \\
\text { PE: } 1\end{array}$ & $\begin{array}{l}\text { Hospital } \\
\text { stay }\end{array}$ \\
\hline & & GCS & 56 & Applied GCS pre-operatively. & $\begin{array}{l}\text { DVT: } 14 / 112 \\
\text { (limbs) } \\
\text { PE: } 1\end{array}$ & $\begin{array}{l}\text { Hospital } \\
\text { stay }\end{array}$ \\
\hline \multirow[t]{2}{*}{$\begin{array}{l}\text { Nagata et al. } \\
\text { Japan }\end{array}$} & 2015 & IPC & 14 & $\begin{array}{l}\text { Used IPC immediately prior to } \\
\text { surgery, until full ambulation } \\
\text { post operation. }\end{array}$ & $\begin{array}{l}\text { DVT: } 3 \\
\text { PE: } 3\end{array}$ & $\begin{array}{l}\text { 9-11 days; } \\
\text { Hospital } \\
\text { stay }\end{array}$ \\
\hline & & LMWH & 16 & $\begin{array}{l}\text { 20mg enoxaparin initiated at } \\
\text { 9:30 PM on postoperative day } 2 \\
\text { and continued for } 7 \text { days. }\end{array}$ & $\begin{array}{l}\text { DVT: } 1 \\
\text { PE: } 0\end{array}$ & $\begin{array}{l}\text { 9-11 days; } \\
\text { Hospital } \\
\text { stay }\end{array}$ \\
\hline
\end{tabular}

IPC: Intermittent Pneumatic Compression; LMWH: low molecular weight heparin; GCS: graduated compression stockings; DVT: deep vein thrombosis; PE: pulmonary embolism. 
Table 2: Study population and VTE measurements of included trials

\begin{tabular}{|c|c|c|c|}
\hline Study & Inclusion criteria & Exclusion criteria & VTE measurements \\
\hline $\begin{array}{l}\text { Clarke Pearson and Synan } \\
\text { et al. } \\
1984\end{array}$ & $\begin{array}{l}\text { Patients undergoing major } \\
\text { surgery for confirmed or } \\
\text { presumed gynecologic } \\
\text { malignancies. }\end{array}$ & $\begin{array}{l}\text { Those had received } \\
\text { anticoagulants or } \\
\text { with acute venous } \\
\text { thromboembolic } \\
\text { complications. }\end{array}$ & $\begin{array}{l}{ }^{125} \text { I-fibrinogen counting and } \\
\text { impedance plethysmography; } \\
\text { suspicious DVT or PE was } \\
\text { evaluated with venography, } \\
\text { ventilation perfusion lung } \\
\text { scanning or pulmonary } \\
\text { arteriography. }\end{array}$ \\
\hline $\begin{array}{l}\text { Clarke Pearson and } \\
\text { Creasmann et al. } \\
1984\end{array}$ & $\begin{array}{l}\text { Patients undergoing major } \\
\text { surgery for known or presumed } \\
\text { gynecologic malignancies. }\end{array}$ & $\begin{array}{l}\text { Patients had VTE within } 3 \\
\text { months or those had taken } \\
\text { anticoagulants within } 6 \\
\text { months. }\end{array}$ & $\begin{array}{l}{ }^{125} \text { I-fibrinogen counting and } \\
\text { impedance plethysmography; } \\
\text { suspicious DVT or PE was } \\
\text { evaluated with venography, } \\
\text { ventilation perfusion lung } \\
\text { scanning or pulmonary } \\
\text { arteriography. }\end{array}$ \\
\hline $\begin{array}{l}\text { Clarke-Pearson and Synan } \\
\text { et al. } \\
1993\end{array}$ & $\begin{array}{l}\text { Patients undergoing major } \\
\text { surgery for known or presumed } \\
\text { gynecologic malignancies. }\end{array}$ & $\begin{array}{c}\text { A history of a } \\
\text { bleeding diathesis, } \\
\text { thromboembolism within } \\
3 \text { months, or receiving } \\
\text { anticoagulation within } 6 \\
\text { weeks }\end{array}$ & $\begin{array}{c}\text { Impedance plethysmography, } \\
\text { duplex Doppler } \\
\text { ultrasonography, and } \\
\text { ascending contrast } \\
\text { venography. Further } \\
\text { ventilation-perfusion } \\
\text { lung scan and pulmonary } \\
\text { arteriography for suspicious } \\
\text { PE }\end{array}$ \\
\hline $\begin{array}{l}\text { Maxwell et al. } \\
2001\end{array}$ & $\begin{array}{c}\text { More than } 40 \text { years old, } \\
\text { underwent major abdominal } \\
\text { or pelvic surgeryfor diagnosed } \\
\text { or suspected gynecologic } \\
\text { malignancy. }\end{array}$ & $\begin{array}{l}\text { DVT or PE within } \\
\text { 6months; contraindications } \\
\text { to heparin therapy; } \\
\text { conduction anesthesia; } \\
\text { history of heparin } \\
\text { sensitivity; pregnancy; } \\
\text { or history of coagulation } \\
\text { abnormalities. }\end{array}$ & $\begin{array}{l}\text { Real-time ultrasound } \\
\text { compression technique } \\
\text { with duplex and color } \\
\text { Doppler imaging. Follow- } \\
\text { up telephone to question } \\
\text { patients regarding VTE signs } \\
\text { and symptoms. }\end{array}$ \\
\hline $\begin{array}{l}\text { Yang et al. } \\
2009\end{array}$ & $\begin{array}{l}\text { Patients undergoing } \\
\text { gynecological surgeries with } \\
\text { high risk factor. }\end{array}$ & No specific description. & $\begin{array}{l}\text { Ultrasonography } \\
\text { examination of lower } \\
\text { extremity. }\end{array}$ \\
\hline $\begin{array}{l}\text { Gao et al. } \\
2012\end{array}$ & $\begin{array}{l}\text { Patients undergoing } \\
\text { gynecological pelvicsurgery } \\
\text { with high-risk factors for DVT, } \\
\text { aged more than } 60 \text { years old, a } \\
\text { history of VTE, heart disease } \\
\text { or varicose veins. }\end{array}$ & $\begin{array}{c}\text { Thrombophlebitis; Acute } \\
\text { DVT; } \\
\text { Platelet count }<100 \times 10^{9} / \mathrm{L} \\
\text { or coagulopathy; } \\
\text { spontaneous bleeding } \\
\text { within six months; } \\
\text { pulmonary edema etc. }\end{array}$ & $\begin{array}{l}\text { Color Doppler flow imaging } \\
\text { for DVT, and tomographic } \\
\text { pulmonary angiography test } \\
\text { if DVT was diagnosed. }\end{array}$ \\
\hline $\begin{array}{l}\text { Nagata et al. } \\
2015\end{array}$ & $\begin{array}{l}\text { over } 40 \text { years old and } 40 \mathrm{~kg} \\
\text { weight, underwent major } \\
\text { abdominal or pelvic surgery, } \\
\text { with confirmed or suspected } \\
\text { gynecologic malignancy }\end{array}$ & $\begin{array}{l}\text { Preoperative confirmed } \\
\text { VTE, hypersensitivity to } \\
\text { heparin, severe liver or } \\
\text { renal dysfunction, active } \\
\text { bleeding etc. }\end{array}$ & $\begin{array}{l}\text { Chest, abdominal, and } \\
\text { lower extremities contrast- } \\
\text { enhanced CT scan for DVT } \\
\text { and PE. }\end{array}$ \\
\hline
\end{tabular}

VTE: venous thromboembolism prophylaxis. Other abbreviations as in Table 1. 
$=0.33,95 \%$ CI: $0.16-0.66$ ), however, short-dated (no more than 24 hours) use of IPC did not reduce the risk of DVT $(\mathrm{RR}=1.5,95 \% \mathrm{CI}: 0.76-2.94)$. The incidence of DVT in IPC and drugs group was 4.5\% (12 out of 268 ) and $3.99 \%$ (11 out of 276 ), respectively, and no significant between-group difference was observed (RR $=1.19,95 \% \mathrm{CI}: 0.42-3.44)$. According to the study by Gao et al. [17], which counted two lower limbs as two samples, the combination of IPC and GCS had a marginally lower risk of DVT than GCS alone (RR = 0.38, 95\% CI: $0.14-1.03)$.

\section{IPC use for PE prophylaxis}

Six articles reported the rate of PE [12-15, 17, 18]. Two studies reported of no incidence of PE [14, 15]. As displayed in Figure 3, compared with control, neither routine $(\mathrm{RR}=1.89,95 \% \mathrm{CI} 0.18-20.23)$ or short- dated $(\mathrm{RR}=4.0,95 \% \mathrm{CI}: 0.46-35.14)$ use of IPC alter the risk of PE. Compared with drugs ( $0 \%, 0$ out of 227$)$, the frequency of PE was 1.4\% (3 out of 221) in IPC group, however, no significant difference was found between IPC and drugs $(\mathrm{RR}=7.47,95 \% \mathrm{CI}: 0.42-132.78)$. The rate of PE was similar in IPC plus GCS group (1 out of 52) and GCS alone group ( 1 out of 56$)(\mathrm{RR}=1.08,95 \% \mathrm{CI}$ $0.07-16.78)$.

\section{IPC use for transfusion rate}

Three trials mentioned perioperative transfusion rate in IPC and drugs group [14, 15, 18]. Compared with heparin, IPC was associated with a lower postoperative transfusion rate $(16.8 \%$ in IPC vs. $31.8 \%$ in heparin, RR $=0.53,95 \%$ CI: $0.32-0.89)$ (Figure 4). Compared with LWMH, patients treated with IPC had a similar transfusion rate in operating room $(\mathrm{RR}=1.06,95 \% \mathrm{CI}$ : $0.69-1.63)$ (Figure 4).

\section{Sensitivity analysis}

Sensitivity meta-analyses by applying fixed-effect model did not observe significant change in above results (Supplementary Figure 3).

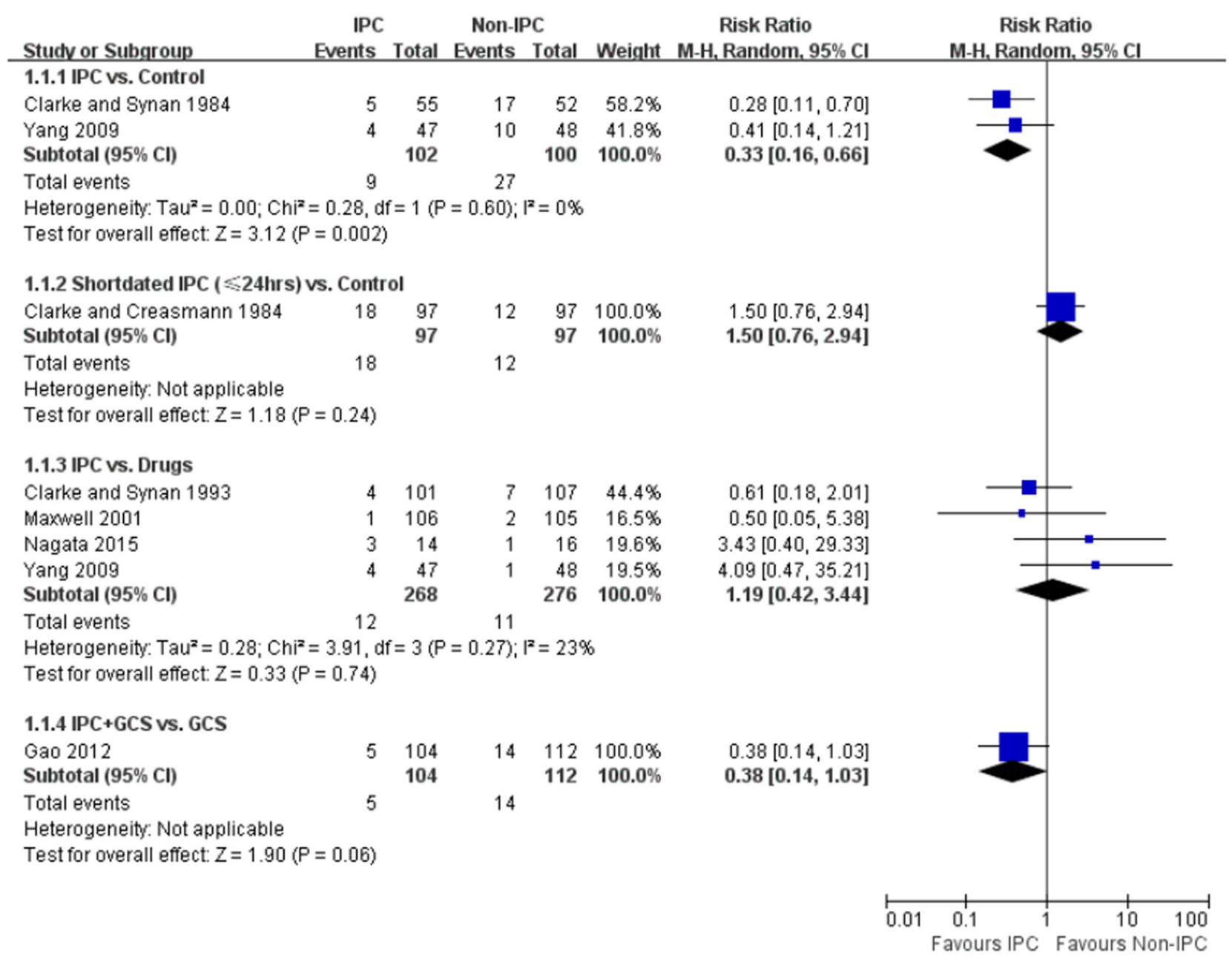

Figure 2: Forest plot of the effectiveness of IPC on DVT prophylaxis, stratified by IPC duration and comparator. 


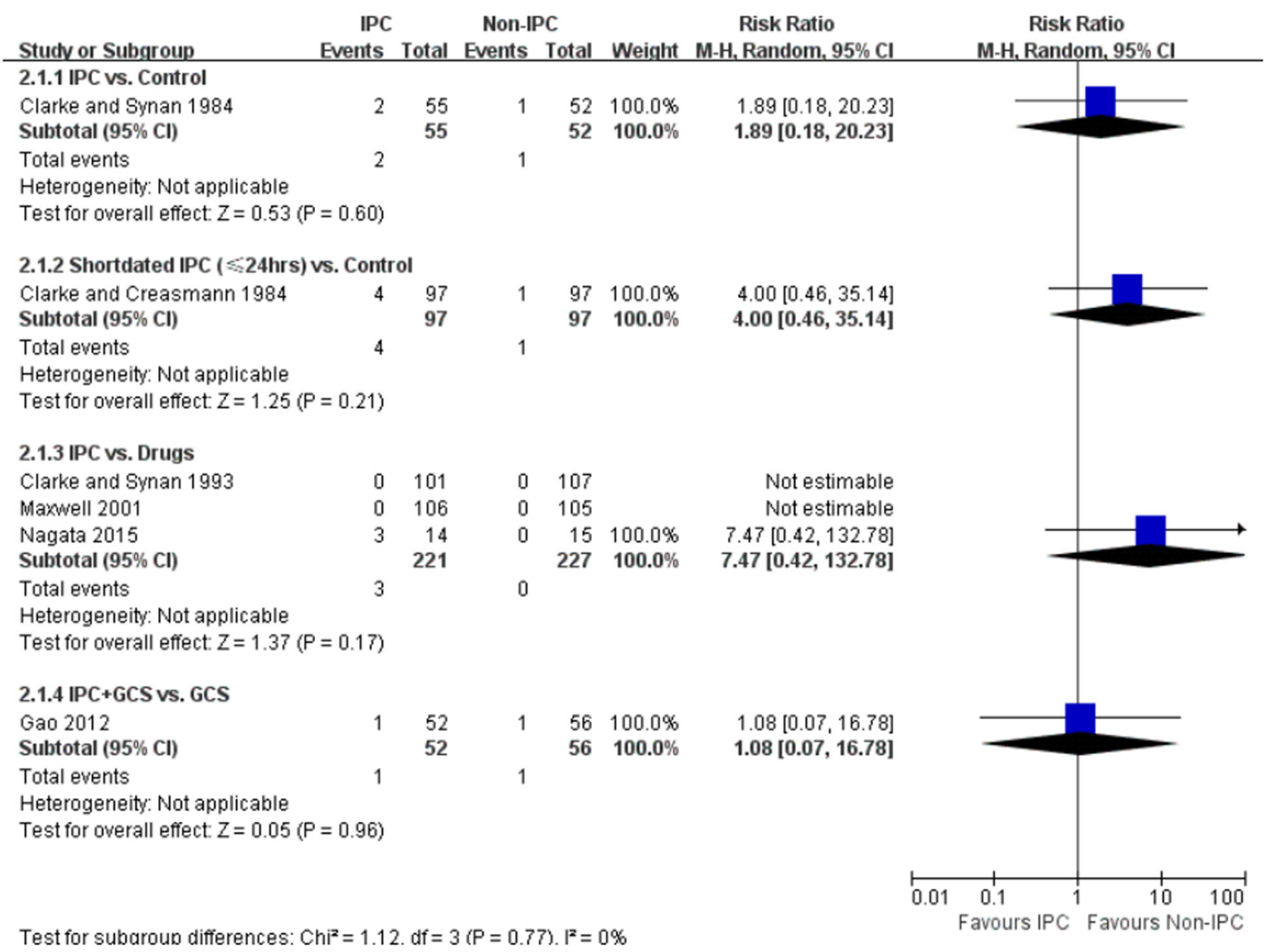

Figure 3: Forest plot of the effectiveness of IPC on PE prophylaxis, stratified by IPC duration and comparator.

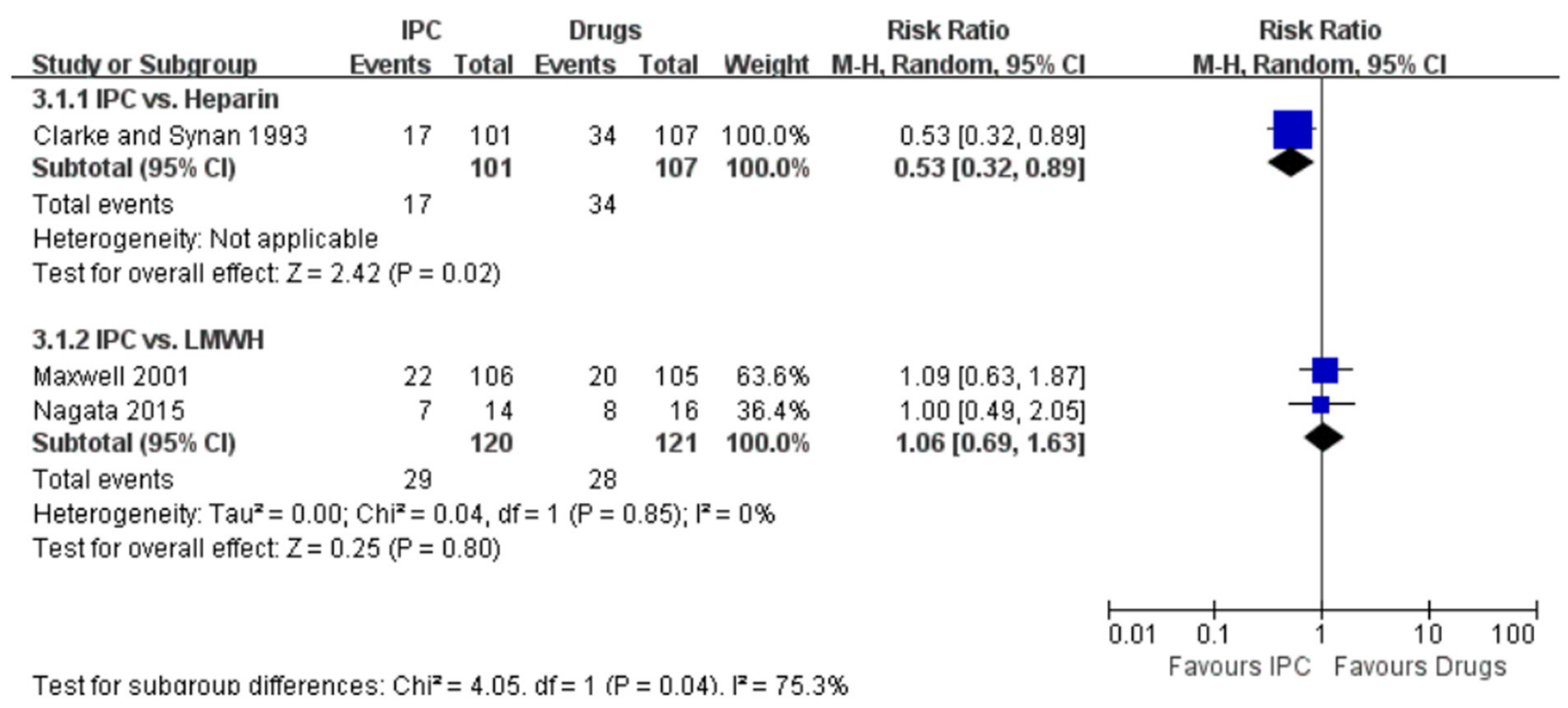

Figure 4: Forest plot of perioperative transfusion rate, stratified by comparator agent. 


\section{DISCUSSION}

A majority of our study population are with gynecologic malignancies. Without VTE prophylaxis, reported postoperative incidence of DVT was as high as $37.9 \%$ in patients with gynecologic cancer [19]. Death occurs frequently in VTE cases, and approximately $12 \%$ of PE patients die within 30 days of diagnosis [1]. Therefore, prophylaxis for perioperative VTE is of great importance. Antithrombotic drugs are strongly recommended for patients with high risk of VTE, however, the nature of anticoagulants, including heparin and $\mathrm{LWMH}$, may preclude clinicians from using these drugs timely. A major concern is the bleeding risk with anticoagulants. Anticoagulation may contribute to increased blood loss and transfusion rate during procedures. Furthermore, major bleeding in hospitalized surgical patients is an important predictor of mortality [20]. IPC is a popular mechanical thromboprophylaxis used in surgical patients. A previous meta-analysis demonstrated that IPC was effective in reducing VTE complications in hospitalized patients in comparison to control or thromboembolic deterrent stockings, with a lower risk of bleeding than pharmacological thromboprophylaxis [21]. However, that study included various hospitalized patients, including general surgical, critically ill and trauma patients. Hence the evidence might not be applicable to gynecological surgery patients. Recently, O'Connell et al. evaluated the use of IPC in orthopedic and neurosurgical postoperative patients, and found that IPC alone was neither superior nor inferior to pharmacological thromboprophylaxis [22]. Again, the evaluation of IPC use was not conducted in gynecological surgery subjects. Thus we performed this meta-analysis focusing on the use of IPC in patients undergoing gynecologic surgery.

In our analysis, we found that routine use of IPC (maintained for 5 days or until full ambulation) lowered DVT risk compared with control, but a short-dated IPC use (until discharge from the recovery room or 24 hours after operation) could not produce preventive effect. This suggests that IPC duration may affect the efficacy of IPC prophylaxis. Future studies may further explore the ideal IPC duration in gynecological surgery patients. Surprisingly, IPC and control had similar rate of PE, this may explained by the limited sample size, more large trials are needed.

Since IPC was effective in thromboprophylaxis, whether it is superior or inferior to chemoprophylaxis is of high interesting. In our pooled analysis, we found that IPC showed neither superiority nor inferiority to drugs in prevention for VTE, which is consistent with a previous meta-analysis in orthopedic and neurosurgical patients [22]. Furthermore, we observed that IPC had a lower rate of postoperative transfusion rate than heparin, and a similar rate of transfusion rate in operating room to LWMH. These findings indicate IPC or LWMH might be safer than heparin in gynecological surgery patients. However, the dose of heparin or LWMH may significantly influence the bleeding complications. As previously reported in gynecological surgery, compared with 5000 units heparin twice-daily, bleeding risk was higher in 5000 units LWMH daily but not in 2500 units LWMH daily $[23,24]$. Due to the limited sample size, the difference in bleeding risk between IPC and drugs remains to be further investigated.

No studies but the one by Gao et al. evaluated the combined use of IPC and another thromboprophylaxis [17]. IPC plus another mechanical method--GCS, seemed more effective than GCS alone. Sachdeva et al. advocated that GCS on a background of another prophylactic method was superior to the other method alone in DVT prophylaxis [25]. In this case, it is reasonable to compare the combination of IPC and chemoprophylaxis with IPC or chemoprophylaxis alone. Turpie et al. showed that IPC plus fondaparinux $2.5 \mathrm{mg}$ reduced risk of VTE by approximately $70 \%$, compared with IPC alone, in abdominal surgery [26]. Unfortunately, in patients undergoing gynecologic surgery, no specific randomized trials have investigated this issue.

\section{Limitations}

Several limitations of our study should be noticed. First, included studies were rather heterogeneous in many respects. Follow up time ranged from hospital stay to 42 days, drug regimens were various, comparator was control, drugs or GCS. Especially, as shown in Table 2, there are variations in VTE measurements and diagnostic strategy, which may affect observed incidences of thromboembolism. However, these measurements were all validated in clinical practice, and both symptomatic and "silent" VTE (a combination of the two) are all relevant to patients' health. Second, the small number of included studies may produce publication bias, which has been estimated by the funnel plot. However, the test power of funnel plots becomes low in such a meta-analysis involving 7 studies. Last, it is difficult to achieve blinding of participants in such trials, and thus performance bias cannot be excluded.

In conclusion, IPC is effective in reducing DVT complications in gynecologic surgery. IPC is neither superior nor inferior to pharmacological thromboprophylaxis, but might be safer than heparin in patients undergoing gynecologic surgery. However, whether combination of IPC and chemoprophylaxis is more effective than IPC or chemoprophylaxis alone remains unknown in these patients. 


\section{MATERIALS AND METHODS}

We performed this systematic review and metaanalysis in accordance with the PRISMA guidelines [27].

\section{Data sources and literature search}

A computerized literature search was conducted in Pubmed, Embase and Cochrane Library databases by two investigators (YTX and JPF) independently, from inception through July 2016. The following searching terms were used: pneumatic compression, sequential compression, external compression, intermittent compression, venous thromboembolism, deep vein thrombosis, pulmonary embolism, gynecological and gynecology. No language restriction was applied. We also searched potentially eligible articles in the reference lists of retrieved records.

\section{Study selection}

Any RCT that evaluated the use of IPC in gynecologic surgery was included. Namely, RCTs that compared IPC with control or drugs, and those compared a treatment plus IPC with that treatment alone were all included. Observational studies and review articles were excluded. Studies that did not report outcomes of interest were excluded either. Titles and/or abstracts were screened by two separate investigators (JPF and ZQF). After removing obviously irrelevant articles, remained full texts were further evaluated for eligibility. Any disagreement was resolved by a third party (ZJG).

\section{Data extraction and quality assessment}

Two reviewers (YTX and JPF) separately extracted data of finally identified articles, including study population, publication year, follow up duration, treatment regimen, occurrence of VTE complications (i.e. DVT and/or PE), perioperative transfusion rate and outcome measurements. The frequencies of VTE and transfusion rate were taken as efficacy and safety endpoints, respectively. The quality assessment of included studies was conducted by the mean of Cochrane Collaboration Risk of Bias Tool. (Supplementary Figure 1)

\section{Data synthesis and statistical analysis}

Mantel-Haenszel method was applied to pool data on efficacy and safety outcomes, with a random-effect model. The overall effect estimates of the outcomes were all reported as risk ratios (RR) and 95\% confidence interval (CI). The heterogeneity between included studies was estimated using $\mathrm{I}^{2}$ test. We considered heterogeneity significant if $\mathrm{I}^{2}$ value was more than $50 \%$. Fixed-effect model was also applied as the sensitivity analysis if $\mathrm{I}^{2}$ value was smaller than $50 \%$. Publication bias was assessed by the funnel plot. Necessary subgroup analyses were also performed, stratified by comparator or treatment regimen. The software Review manager (version 5.2) provided by Cochrane Collaboration was used for all statistical analysis.

\section{CONFLICTS OF INTEREST}

The authors declare no conflicts of interest.

\section{FUNDING}

This work was supported by the Project Funded by the Six Major Talent Peak of Jiangsu Province (2015WSW-029).

\section{REFERENCES}

1. White RH. The epidemiology of venous thromboembolism. Circulation. 2003; 107: I4-8. doi: 10.1161/01. cir.0000078468.11849.66.

2. Heit JA, Silverstein MD, Mohr DN, Petterson TM, Lohse CM, O'Fallon WM, Melton LJ 3rd. The epidemiology of venous thromboembolism in the community. Thromb Haemost. 2001; 86: 452-63.

3. White RH, Zhou H, Romano PS. Incidence of symptomatic venous thromboembolism after different elective or urgent surgical procedures. Thromb Haemost. 2003; 90: 446-55. doi: 10.1160/th03-03-0152.

4. Caprini JA. Thrombosis risk assessment as a guide to quality patient care. Dis Mon. 2005; 51: 70-8. doi: 10.1016/j.disamonth.2005.02.003.

5. Geerts WH, Pineo GF, Heit JA, Bergqvist D, Lassen MR, Colwell CW, Ray JG. Prevention of venous thromboembolism: the Seventh ACCP Conference on Antithrombotic and Thrombolytic Therapy. Chest. 2004; 126: 338s-400s. doi: 10.1378/chest.126.3_suppl.338S.

6. Monagle P, Chan A, Massicotte P, Chalmers E, Michelson AD. Antithrombotic therapy in children: the Seventh ACCP Conference on Antithrombotic and Thrombolytic Therapy. Chest. 2004; 126: 645s-87s. doi: 10.1378/ chest.126.3_suppl.645S.

7. Ginzburg E, Dujardin F. Physicians' perceptions of the definition of major bleeding in major orthopedic surgery: results of an international survey. J Thromb Thrombolysis. 2011; 31: 188-95. doi: 10.1007/s11239-010-0498-9.

8. Geerts WH, Bergqvist D, Pineo GF, Heit JA, Samama CM, Lassen MR, Colwell CW. Prevention of venous thromboembolism: American College of Chest Physicians Evidence-Based Clinical Practice Guidelines (8th Edition). Chest. 2008; 133: 381s-453s. doi: 10.1378/chest.08-0656.

9. Guyatt GH, Akl EA, Crowther M, Gutterman DD, Schuunemann HJ. Executive summary: Antithrombotic Therapy and Prevention of Thrombosis, 9th ed: American 
College of Chest Physicians Evidence-Based Clinical Practice Guidelines. Chest. 2012; 141: 7s-47s. doi: 10.1378/ chest.1412S3.

10. Rahn DD, Mamik MM, Sanses TV, Matteson KA, Aschkenazi SO, Washington BB, Steinberg AC, Harvie HS, Lukban JC, Uhlig K, Balk EM, Sung VW. Venous thromboembolism prophylaxis in gynecologic surgery: a systematic review. Obstet Gynecol. 2011; 118: 1111-25. doi: 10.1097/AOG.0b013e318232a394.

11. Levitan N, Dowlati A, Remick SC, Tahsildar HI, Sivinski LD, Beyth R, Rimm AA. Rates of initial and recurrent thromboembolic disease among patients with malignancy versus those without malignancy. Risk analysis using Medicare claims data. Medicine (Baltimore). 1999; 78: 28591. doi: 10.1097/00005792-199909000-00001.

12. Clarke Pearson DL, Synan IS, Hinshaw WM. Prevention of postoperative venous thromboembolism by external pneumatic calf compression in patients with gynecologic malignancy. Obstetrics and Gynecology. 1984; 63: 92-8.

13. Clarke-Pearson DL, Creasmann WT, Coleman RE. Perioperative external pneumatic calf compression as thromboembolism prophylaxis in gynecologic oncology: Report of a randomized controlled trial. Gynecologic Oncology. 1984; 18: 226-32. doi: 10.1016/0090-8258(84)90030-1.

14. Clarke-Pearson DL, Synan IS, Dodge R, Soper JT, Berchuck A, Coleman RE. A randomized trial of low-dose heparin and intermittent pneumatic calf compression for the prevention of deep venous thrombosis after gynecologic oncology surgery. Am J Obstet Gynecol. 1993; 168: 114653; discussion 53-4. doi: 10.1016/0002-9378(93)90360-U.

15. Maxwell GL, Synan I, Dodge R, Carroll B, Clarke-Pearson DL. Pneumatic compression versus low molecular weight heparin in gynecologic oncology surgery: A randomized trial. Obstetrics and Gynecology. 2001; 98: 989-95. doi: 10.1016/S0029-7844(01)01601-5.

16. Yang BL, Zhang ZY, Guo SL. [Clinical significance of preventive treatment of thrombosis for patients undergoing gynecological surgery with high risk factors]. Zhonghua $\mathrm{Fu}$ Chan Ke Za Zhi. 2009; 44: 570-3. doi: 10.3760/ cma.j.issn.0529-567x.2009.08.004.

17. Gao J, Zhang ZY, Li Z, Liu CD, Zhan YX, Qiao BL, Sang CQ, Guo SL, Wang SZ, Jiang Y, Zhao N. Two mechanical methods for thromboembolism prophylaxis after gynaecological pelvic surgery: a prospective, randomised study. Chin Med J (Engl). 2012; 125: 4259-63. doi: 10.3760/cma.j.issn.0366-6999.2012.23.018.

18. Nagata C, Tanabe H, Takakura S, Narui C, Saito M, Yanaihara N, Okamoto A. Randomized controlled trial of enoxaparin versus intermittent pneumatic compression for venous thromboembolism prevention in Japanese surgical patients with gynecologic malignancy. J Obstet Gynaecol Res. 2015; 41: 1440-8. doi: 10.1111/jog. 12740.

19. Crandon AJ, Koutts J. Incidence of post-operative deep vein thrombosis in gynaecological oncology. Aust N Z J Obstet Gynaecol. 1983; 23: 216-9. doi: 10.1111/j.1479-828X.1983. tb00581.x.

20. Eikelboom JW, Quinlan DJ, O'Donnell M. Major bleeding, mortality, and efficacy of fondaparinux in venous thromboembolism prevention trials. Circulation. 2009; 120: 2006-11. doi: 10.1161/circulationaha.109.872630.

21. Ho KM, Tan JA. Stratified meta-analysis of intermittent pneumatic compression of the lower limbs to prevent venous thromboembolism in hospitalized patients. Circulation. 2013; 128: 1003-20. doi: 10.1161/ circulationaha.113.002690.

22. O'Connell S, Bashar K, Broderick BJ, Sheehan J, Quondamatteo F, Walsh SR, G OL, Quinlan LR. The Use of Intermittent Pneumatic Compression in Orthopedic and Neurosurgical Postoperative Patients: A Systematic Review and Meta-analysis. Ann Surg. 2016; 263: 888-9. doi: 10.1097/sla.0000000000001530.

23. Borstad E, Urdal K, Handeland G, Abildgaard U. Comparison of low molecular weight heparin vs. unfractionated heparin in gynecological surgery. Acta Obstet Gynecol Scand. 1988; 67: 99-103. doi: 10.3109/00016348809004178.

24. Borstad E, Urdal K, Handeland G, Abildgaard U. Comparison of low molecular weight heparin vs. unfractionated heparin in gynecological surgery. II: Reduced dose of low molecular weight heparin. Acta Obstet Gynecol Scand. 1992; 71: 471-5. doi: 10.3109/00016349209021097.

25. Sachdeva A, Dalton M, Amaragiri SV, Lees T. Elastic compression stockings for prevention of deep vein thrombosis. Cochrane Database Syst Rev. 2010: Cd001484. doi: 10.1002/14651858.CD001484.pub2.

26. Turpie AG, Bauer KA, Caprini JA, Comp PC, Gent M, Muntz JE. Fondaparinux combined with intermittent pneumatic compression vs. intermittent pneumatic compression alone for prevention of venous thromboembolism after abdominal surgery: a randomized, double-blind comparison. J Thromb Haemost. 2007; 5: 1854-61. doi: 10.1111/j.1538-7836.2007.02657.x.

27. Liberati A, Altman DG, Tetzlaff J, Mulrow C, Gotzsche PC, Ioannidis JP, Clarke M, Devereaux PJ, Kleijnen J, Moher D. The PRISMA statement for reporting systematic reviews and meta-analyses of studies that evaluate health care interventions: explanation and elaboration. PLoS Med. 2009; 6: e1000100. doi: 10.1371/journal.pmed.1000100. 